\title{
Salipiger mucescens gen. nov., sp. nov., a moderately halophilic, exopolysaccharide- producing bacterium isolated from hypersaline soil, belonging to the $\alpha$-Proteobacteria
}

\author{
M. José Martínez-Cánovas, Emilia Quesada, Fernando Martínez-Checa, \\ Ana del Moral and Victoria Béjar
}

Correspondence Victoria Béjar vbejar@ugr.es

\begin{abstract}
Microbial Exopolysaccharide Research Group, Department of Microbiology, Faculty of Pharmacy, Cartuja Campus, University of Granada, 18071 Granada, Spain
\end{abstract}

\begin{abstract}
Salipiger mucescens gen. nov., sp. nov. is a moderately halophilic, exopolysaccharide-producing, Gram-negative rod isolated from a hypersaline habitat in Murcia in south-eastern Spain. The bacterium is chemoheterotrophic and strictly aerobic (i.e. unable to grow under anaerobic conditions either by fermentation or by nitrate or fumarate respiration). It does not synthesize bacteriochlorophyll a. Catalase and phosphatase are positive. It does not produce acids from carbohydrates. It cannot grow with carbohydrates or amino acids as sole sources of carbon and energy. It grows best at 9-10\% w/v NaCl and requires the presence of $\mathrm{Na}^{+}$but not $\mathrm{Mg}^{2+}$ or $\mathrm{K}^{+}$, although they do stimulate its growth somewhat when present. Its major fatty-acid component is $18: 1 \omega 7 c(78 \cdot 0 \%)$. The predominant respiratory lipoquinone found in strain $\mathrm{A}^{\top}$ is ubiquinone with ten isoprene units. The $\mathrm{G}+\mathrm{C}$ content is $64.5 \mathrm{~mol} \%$. Phylogenetic analyses strongly indicate that this strain forms a distinct line within a clade containing the genus Roseivivax in the subclass $\alpha$-Proteobacteria. The similarity value with Roseivivax halodurans and Roseivivax halotolerans is $94 \%$. In the light of the polyphasic evidence gathered in this study it is proposed that the isolate be classified as representing a new genus and species, Salipiger mucescens gen. nov., sp. nov. The proposed type strain is strain $A 3^{T}$

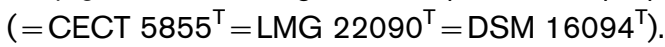

Moderately halophilic bacteria are widely distributed throughout hypersaline habitats and require from 3 to $15 \% \mathrm{w} / \mathrm{v} \mathrm{NaCl}$ for satisfactory growth (Kushner \& Kamekura, 1988). In recent years it has been found that several products of these bacteria, such as exopolysaccharides (EPSs), halophilic enzymes and compatible solutes, may have very useful applications in biotechnology (Ventosa, 2004; Ventosa et al., 1998). During an extensive search of many different hypersaline habitats in Spain and Morocco designed to obtain new EPSs we discovered that the commonest halophilic EPS producers were various novel species of the genus Halomonas, most importantly Halomonas maura and Halomonas eurihalina (Bouchotroch et al., 2001; Martínez-Cánovas et al., 2004c; Quesada et al., 1990, 2004), together, to a lesser extent, with Halomonas ventosae (Martínez-Cánovas et al., 2004a) and Halomonas

Published online ahead of print on 9 July 2004 as DOI 10.1099/ ijs.0.63166-0.

Abbreviations: EPS, exopolysaccharide; PHA, poly- $\beta$-hydroxyalkanoate. The GenBank/EMBL/DDBJ accession number for the 16S rRNA gene sequence of strain $A 3^{\top}$ is $A Y 527274$. anticariensis (Martínez-Cánovas et al., 2004b). We describe and classify here a hitherto unassigned halophilic EPSproducing strain that was also isolated in these studies. On the basis of its phenotypic features, comparative studies of its 16S rRNA gene sequence and investigations into its polar-lipid and isoprenoid quinone contents, together with its salt requirements and its inability to synthesize bacteriochlorophyll $a$, we propose that this bacterium should be assigned to a new genus, Salipiger, with a single species Salipiger mucescens gen. nov., sp. nov.

The strain named $\mathrm{A} 3^{\mathrm{T}}$ was isolated from a saline soil bordering a saltern on the Mediterranean coast at Calblanque (Murcia, south-eastern Spain) (MartínezCánovas et al., 2004c). The strain was routinely grown at $32{ }^{\circ} \mathrm{C}$ in MY medium (Quesada et al., 1993) supplemented with a $7 \cdot 5 \% \mathrm{w} / \mathrm{v}$ sea-salt solution (Rodríguez-Valera et al., 1981).

An initial phenotypic study including 135 tests was undertaken by Martínez-Cánovas et al. (2004c). Salt requirements and optimum salt concentration were determined in MY medium according to the methods described by Bouchotroch 
et al. (2001). The salt concentrations assayed ranged from 0.5 to $30 \% \mathrm{w} / \mathrm{v}$ and were prepared from a mixture of sea salts according to Rodríguez-Valera et al. (1981). We also tested to see whether strain $\mathrm{A}^{\mathrm{T}}$ could survive with $\mathrm{NaCl}$ alone or whether it required other magnesium and/or potassium salts.

Bacteriochlorophyll $a$ was analysed spectrophotometrically using the procedure of Cohen-Bazire et al. (1957) following the recommendations of Allgaier et al. (2003). Two microlitres of a liquid culture of strain $\mathrm{A} 3^{\mathrm{T}}$ incubated in the dark was centrifuged and the pellet resuspended in a drop of the remaining medium. A $1.5 \mathrm{ml}$ volume of an ice-cold $\left(-20^{\circ} \mathrm{C}\right)$ acetone/methanol solution $(7: 2 \mathrm{v} / \mathrm{v})$ was added, mixed thoroughly and incubated at room temperature in the dark for $12 \mathrm{~h}$. After centrifugation, spectrophotometric measurements were made at $600-900 \mathrm{~nm}$.

Fatty acids and quinones were identified by high-resolution GLC and HPLC respectively at the DSMZ.

Transmission electron micrographs were made using the methods described by Bouchotroch et al. (2001).

The 16S rRNA gene was amplified by PCR using standard protocols (Saiki et al., 1988). The forward primer, 16F27 (5'-AGAGTTTGATCMTGGCTCAG-3'), annealed at positions 8-27 and the reverse primer, 16R1488 (5'-CGGTTACCTTGTTAGGACTTCACC-3') (both from Pharmacia), annealed at the complement of positions 1511-1488 (Escherichia coli numbering according to Brosius et al., 1978). The PCR products were purified using the QIAquick spin-gel extraction kit (Qiagen). Direct sequence determinations of PCR-amplified DNAs were carried out with the ABI PRISM dye-terminator cycle-sequencing readyreaction kit (Perkin-Elmer) and an ABI PRISM 377 sequencer (Perkin-Elmer) according to the manufacturer's instructions. The sequences obtained were compared to reference 16S rRNA gene sequences available in the GenBank, EMBL and DDBJ databases obtained from the National Center of Biotechnology Information database using the BLAST search. Phylogenetic analysis was performed using the software MEGA version 2.1 (Kumar et al., 2001) after multiple alignments of data by CLUSTAL $\mathrm{x}$ (Thompson et al., 1997). Distances and clustering were determined using the neighbour-joining and maximum-parsimony methods. The stability of clusters was ascertained by performing a bootstrap analysis (1000 replications).

The strain described here was isolated during a wide research programme, the main objective of which was to identify EPS-producing bacteria in different hypersaline habitats (Martínez-Cánovas et al., 2004c; Quesada et al., 2004). Numerical analysis of its phenotypic characteristics demonstrated that strain $\mathrm{A} 3^{\mathrm{T}}$ was not related to other halophilic EPS-producing strains isolated from these habitats (Martínez-Cánovas et al., 2004c). $\mathrm{A} 3^{\mathrm{T}}$ was also found to contain at least seven plasmids $(550,467,184$, $140 \cdot 8,110 \cdot 6,98 \cdot 2$ and $30 \cdot 8 \mathrm{~kb}$ ). It did not however contain the $600 \mathrm{~kb}$ megaplasmid found in other halophilic microorganisms (Argandoña et al., 2003). All these facts led us to characterize this strain further and eventually to propose its assignment to a new genus.

Strain $\mathrm{A} 3^{\mathrm{T}}$ is strictly halophilic, being unable to grow in the absence of sea salts. It is an aerobic chemo-organotroph, unable to grow under anaerobic conditions either by fermenting sugars or by reducing nitrate, nitrite or fumarate. Bacteriochlorophyll $a$ was not detected. It is characterized by its low nutritional and biochemical versatility. Its phenotypic characteristics appear in the species description. Phenotypic features that differentiate strain $A 3^{\mathrm{T}}$ from the two species of Roseivivax and other members of the family 'Rhodobacteraceae' related to it phylogenetically are shown in Table 1. The data included in this table demonstrate that there is no phenotypic similarity between $\mathrm{A} 3^{\mathrm{T}}$ and the other strains concerned. The $\mathrm{G}+\mathrm{C}$ content of strain $\mathrm{A} 3^{\mathrm{T}}$ is $64 \cdot 5 \mathrm{~mol} \%$ (Martínez-Cánovas et al., 2004c), which is similar to the value of $64 \cdot 4 \mathrm{~mol} \%$ obtained for Roseivivax halodurans (Suzuki et al., 1999).

Strain $\mathrm{A} 3^{\mathrm{T}}$ contains a large quantity $(78.0 \%)$ of cis- 11 octadecenoic acid $(18: 1 \omega 7 c)$ in combination with $16: 0$, 18:0, 11-methyl-branched cis-9 octadecenoic acid (11-

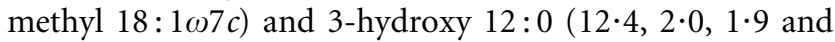
$2 \cdot 3 \%$, respectively). The presence of $18: 1 \omega 7 c$ as the predominant fatty acid is a feature characteristic of several major taxa within the $\alpha$-Proteobacteria (Table 1). Nevertheless, strain $\mathrm{A}^{\mathrm{T}}$ also contains cyclo-substituted fatty acids $(2 \cdot 3 \%)$, which are not widely present in the family 'Rhodobacteraceae'. The fatty acids of the Roseivivax species, which are most phylogenetically related to $A 3^{\mathrm{T}}$, have not been thoroughly described, although in a study published before the taxonomical description of Roseivivax halodurans and Roseivivax halotolerans Nishimura et al. (1994) reported that the main cellular fatty-acid component in these bacteria was $18: 1$. The only respiratory lipoquinone detected was ubiquinone 10 . The presence of ubiquinone 10 as the dominant respiratory lipoquinone is characteristic of members of the $\alpha$-Proteobacteria.

Fig. 1 shows the cell morphology of strain $\mathrm{A} 3^{\mathrm{T}}$. Thin sections reveal a typical Gram-negative cell-envelope profile; the cell contains poly- $\beta$-hydroxyalkanoate (PHA) granules. EPS appears associated with the cell surface.

According to the recommendations of Stackebrandt et al. (2002) we determined the almost complete 16S rRNA gene sequence of strain $\mathrm{A}^{\mathrm{T}}$ (1364 bp), corresponding to positions 46-1445 of the Escherichia coli 16S rRNA gene. The phylogenetic tree obtained via the neighbour-joining method is shown in Fig. 2. The maximum-parsimony algorithm gave a similar result (data not shown). Together with the sequence of $\mathrm{A}^{\mathrm{T}}$, our phylogenetic analysis also included all the representatives of the family 'Rhodobacteraceae' described to date plus four halophilic bacteria belonging to the $\gamma$-Proteobacteria as an outgroup. Strain $\mathrm{A} 3^{\mathrm{T}}$ belongs to a clade containing Roseivivax halodurans 
Table 1. Characteristics that distinguish Salipiger mucescens gen. nov., sp. nov. $A 3^{\top}$ from other related members of the family 'Rhodobacteraceae'

Reference strains: 1 and 2, Roseivivax halodurans JCM $10272^{\mathrm{T}}$ and Roseivivax halotolerans JCM 10271 ${ }^{\mathrm{T}}$ (Suzuki et al., 1999; Nishimura et al., 1994); 3, Antarctobacter heliothermus DSM 11445 (Labrenz et al., 1998); 4, Ketogulonicigenium vulgare DSM 405 $5^{\mathrm{T}}$ (Urbance et al., 2001); 5, Jannaschia helgolandensis DSM 14858 ${ }^{\mathrm{T}}$ (Wagner-Döbler et al., 2003); 6, Leisingera methylohalidivorans ATCC BAA-92 ${ }^{\mathrm{T}}$ (Schaefer et al., 2002); 7, Octadecabacter arcticus CIP 106731 ${ }^{\mathrm{T}}$ (Gosink et al., 1997); 8, Roseobacter litoralis (Shiba, 1991; Labrenz et al., 1998); 9, Roseovarius tolerans DSM 11457 ${ }^{\mathrm{T}}$ (Labrenz et al., 1999); 10, Ruegeria algicola ATCC 51440 ${ }^{\mathrm{T}}$ (Lafay et al., 1995; Labrenz et al., 1998); 11, Sagittula stellata ATCC $700073^{\mathrm{T}}$ (González et al., 1997); 12, Silicibacter lacuscaerulensis DSM 11314 (Petursdottir \& Kristjansson, 1997); 13, Sulfitobacter mediterraneus DSM 12244 ${ }^{\mathrm{T}}$ (Pukall et al., 1999); 14, Staleya guttiformis DSM $11443^{\mathrm{T}}$ (Labrenz et al., 2000). +, Positive; -, negative; W, weak; ND, no data available.

\begin{tabular}{|c|c|c|c|c|c|c|c|c|c|c|c|c|c|c|c|}
\hline Characteristic & S. mucescens & 1 & 2 & 3 & 4 & 5 & 6 & 7 & 8 & 9 & 10 & 11 & 12 & 13 & 14 \\
\hline Morphology & Rods & Rods & Rods & $\begin{array}{l}\text { Pointed rods. } \\
\text { Buds and } \\
\text { rosettes } \\
\text { formed }\end{array}$ & $\begin{array}{l}\text { Ovoid } \\
\text { to rods }\end{array}$ & $\begin{array}{l}\text { Irregular } \\
\text { rods }\end{array}$ & $\begin{array}{l}\text { Rods or } \\
\text { ovoid rods }\end{array}$ & $\begin{array}{l}\text { Long rods. } \\
\text { Gas vacuolate } \\
\text { bacteria }\end{array}$ & $\begin{array}{c}\text { Rods or } \\
\text { ovoid } \\
\text { rods }\end{array}$ & $\begin{array}{l}\text { Pointed and } \\
\text { budded rods }\end{array}$ & Ovoid rods & $\begin{array}{l}\text { Arrow rods with } \\
\text { surface vesicles. } \\
\text { Holdfast and } \\
\text { rosettes formed }\end{array}$ & $\begin{array}{l}\text { Long rods. } \\
\text { Gas vacuolate } \\
\text { bacteria }\end{array}$ & $\begin{array}{ll}\text { Rods. } \\
\text { ate } & \text { Rosettes } \\
& \text { formed }\end{array}$ & $\begin{array}{l}\text { Short rods. } \\
\text { Bud and } \\
\text { rosettes formed }\end{array}$ \\
\hline Source of isolation & $\begin{array}{l}\text { Hypersaline } \\
\text { soil }\end{array}$ & $\begin{array}{c}\text { Charophyte } \\
\text { sp. of a } \\
\text { saline lake }\end{array}$ & $\begin{array}{l}\text { Cyanobac- } \\
\text { terial mats of } \\
\text { a saline lake }\end{array}$ & $\begin{array}{c}\text { Hypersaline } \\
\text { f Antarctic } \\
\text { lake }\end{array}$ & $\begin{array}{l}\text { Soil enriched } \\
\text { with L-sorbose }\end{array}$ & Sea water & $\begin{array}{l}\text { Sea water } \\
\text { enriched with } \\
\text { methyl bromide }\end{array}$ & $\begin{array}{c}\text { Antarctic } \\
\text { sea ice } \\
\text { de }\end{array}$ & $\begin{array}{c}\text { Green } \\
\text { seaweeds }\end{array}$ & $\begin{array}{l}\text { Hypersaline } \\
\text { Antarctic lake }\end{array}$ & $\begin{array}{c}\text { Marine } \\
\text { dinoflagellate }\end{array}$ & Sea water & \multicolumn{2}{|c|}{$\begin{array}{l}\text { Geothermal Sea water } \\
\text { silica saline lake }\end{array}$} & $\begin{array}{l}\text { Hypersaline } \\
\text { Antarctic lake }\end{array}$ \\
\hline Pigment & - & Pink & Pink & Brown-yellow & Brown & - & - & - & Pink & Red & Beige to pink & Cream & Tan & Cream & Beige to pink \\
\hline Flagella ${ }^{*}$ & - & S, sP & S, SP & SP & - & - & + & - & M, SP & + & SP & + & - & M, sp & s \\
\hline PHA & + & ND & ND & + & ND & $\begin{array}{l}\text { White } \\
\text { inclusions }\end{array}$ & ND & ND & ND & + & - & + & - & + & + \\
\hline Oxidase & + & + & + & + & + & $\mathrm{w}$ & + & - & + & $\mathrm{w}$ & + & + & + & + & + \\
\hline Preferred metabolism $\dagger$ & $\mathrm{CH}, \mathrm{AE}$ & $\mathrm{CH}, \mathrm{AE}$ & $\mathrm{CH}, \mathrm{AE}$ & $\mathrm{CH}, \mathrm{AE}$ & $\mathrm{CH}, \mathrm{FA}$ & $\mathrm{CH}, \mathrm{AE}$ & $\mathrm{M}, \mathrm{AE}$ & $\mathrm{CH}, \mathrm{MA}$ & $\mathrm{CH}, \mathrm{AE}$ & $\mathrm{CH}, \mathrm{AE}$ & $\mathrm{CH}, \mathrm{AE}$ & $\mathrm{CH}, \mathrm{AE}$ & $\mathrm{CH}, \mathrm{AE}$ & $\mathrm{CH}, \mathrm{AE}$ & $\mathrm{CH}, \mathrm{AE}$ \\
\hline Anaerobic growth & - & - & - & - & + & - & - & - & - & - & - & - & - & - & - \\
\hline Bacteriochlorophyll $a$ & - & + & + & - & - & - & ND & - & + & + & - & - & - & - & + \\
\hline Growth factor requirement & - & - & - & + & - & - & - & + & + & + & + & $\mathrm{w}$ & - & - & + \\
\hline $\mathrm{Na}^{+}$requirement & + & - & + & + & - & + & + & + & + & + & + & + & + & + & $\mathrm{w}$ \\
\hline Optimum $\mathrm{NaCl}$ concentration (\%) & $9-10$ & ND & ND & $2-6$ & $0 \cdot 01-0 \cdot 2$ & ND & 3 & ND & ND & $1-8$ & ND & ND & 3.5 & $1 \cdot 5-2$ & 1 \\
\hline Salt growth range (\%) & $0 \cdot 5-20$ & $0-20$ & $0 \cdot 5-20$ & $1-10$ & $0-4$ & $1-7$ & $1-6$ & $1 \cdot 7-7$ & ND & $1-15$ & $0 \cdot 5-12$ & ND & $1 \cdot 5-7$ & $0 \cdot 2-8$ & $1-15$ \\
\hline Optimum temperature $\left({ }^{\circ} \mathrm{C}\right)$ & $20-40$ & $27-30$ & $27-30$ & $16-26$ & $27-31$ & $25-30$ & 27 & $4-15$ & $20-30$ & $8 \cdot 5-33 \cdot 5$ & $25-30$ & 30 & 45 & $17-28$ & $12-20$ \\
\hline Nitrate to nitrite & - & + & - & + & ND & - & - & - & - & - & - & - & + & - & + \\
\hline Growth on carbohydrates & - & + & + & + & + & + & - & $\mathrm{w}$ & + & + & + & + & - & + & $\mathrm{w}$ \\
\hline Acids from glucose & - & + & $\mathrm{w} /-$ & - & ND & - & - & $\mathrm{w}$ & - & - & - & - & ND & - & - \\
\hline Major fatty acids§ (\%) & $\begin{array}{c}18: 1 \omega 7 \mathrm{c}(78 \cdot 0), \\
16: 0(12 \cdot 4), \\
18: 0(2 \cdot 0), \\
16: 1 \omega 7 \mathrm{c}(1 \cdot 3)\end{array}$ & $\begin{array}{c}18: 1 \\
\quad(\text { not } \\
\text { quantified) }\end{array}$ & $\begin{array}{c}18: 1 \\
\text { (not } \\
\text { quantified) }\end{array}$ & $\begin{array}{l}18: 1(83 \cdot 2), \\
16: 0(2 \cdot 5) \\
18: 0(1)\end{array}$ & $\begin{array}{c}18: 1 \omega 7 c / \omega 9 t / \\
\omega 12 t(52) \\
16: 0(33 \cdot 5) \\
16: 1 \omega 7 \mathrm{c}(2 \cdot 7)\end{array}$ & $\begin{array}{c}18: 1 \omega 7 \mathrm{c}(45 \cdot 1), \\
18: 0(10 \cdot 8), \\
12: 1(4 \cdot 9), \\
17: 0(1)\end{array}$ & ND & $\begin{array}{c}18: 1 \omega 7 c \\
\omega 9 t / \omega 12 t \\
(75), 16: 1 \omega 7 \mathrm{c} \\
(8), 16: 0(6)\end{array}$ & $\begin{array}{l}18: 1(88 \cdot 8), \\
18: 2(1 \cdot 4), \\
18: 0(1 \cdot 3), \\
16: 0(1 \cdot 1)\end{array}$ & $\begin{array}{l}18: 1(70 \cdot 2), 1 \\
18: 2(10 \cdot 6), \\
16: 0(6 \cdot 2)\end{array}$ & $\begin{array}{c}18: 1 \omega 7 c(91 \cdot 5), \\
18: 0(2 \cdot 2), \\
18: 2(1 \cdot 6), \\
16: 0(1 \cdot 6)\end{array}$ & $\begin{array}{c}18: 1 \omega 7 c \\
\text { (not quantified), } \\
16: 0(8 \cdot 6), \\
18: 0(6 \cdot 8)\end{array}$ & $\begin{array}{rr}\text { ND } & 18 \\
& \\
& 1 \\
& 1\end{array}$ & $\begin{array}{c}18: 1 \omega 11 c(72 \cdot 4), \\
16: 0(6 \cdot 1), \\
16: 1 \omega 7 c(1 \cdot 9), \\
18: 1 \omega 9 c(1 \cdot 7)\end{array}$ & $\begin{array}{c}18: 1 \omega 7 c(79 \cdot 7), \\
18: 2(5 \cdot 3), \\
16: 0(3 \cdot 9) \\
19: 1 \quad(1 \cdot 4)\end{array}$ \\
\hline 3-OH fatty acids & $12: 1(2 \cdot 3)$ & - & - & $12: 1(3 \cdot 1)$ & $\begin{array}{l}10: 0(3 \cdot 6) \\
12: 0(2 \cdot 9)\end{array}$ & $\begin{array}{l}10: 0(5 \cdot 6) \\
14: 1(1 \cdot 3)\end{array}$ & $\mathrm{ND}$ & $10: 0(4)$ & $10: 0(1 \cdot 9)$ & $12: 1(3 \cdot 6)$ & - & $12: 1(3 \cdot 6)$ & ND & $10: 0(2 \cdot 5)$ & $\begin{array}{l}10: 0(5 \cdot 9), \\
14: 1(2 \cdot 1)\end{array}$ \\
\hline 2-OH fatty acids & - & - & - & - & - & - & ND & - & $14: 0(3 \cdot 9)$ & $12: 0(2 \cdot 4)$ & - & - & ND & - & - \\
\hline Methyl fatty acids & $\begin{array}{c}\text { 11-methyl } \\
18: 1 \omega 7 c(1 \cdot 9)\end{array}$ & - & - & - & - & $\begin{array}{c}\text { Methyl } \\
18: 1(5 \cdot 7)\end{array}$ & ND & - & - & - & - & - & $\mathrm{ND}$ & $\begin{array}{c}\text { 10-methyl } \\
18: 1(2 \cdot 6) \\
18 \text {-methyl } \\
18: 1(1 \cdot 4)\end{array}$ & - \\
\hline Cyclo-substituted fatty acids & $\begin{array}{l}19: 0 \text { cyclo } \\
\omega 8 c(2 \cdot 3)\end{array}$ & - & - & 19:0 cyclo $(2 \cdot 4)$ & - & $\begin{array}{l}19: 0 \text { cyclo } \\
(25 \cdot 1)\end{array}$ & ND & - & - & - & - & $19: 0$ cyclo $(1 \cdot 8)$ & ND & - & - \\
\hline Quinone type & Q10 & Q10 & Q10 & Q10 & ND & Q10 & ND & $\mathrm{ND}$ & Q10 & Q10 & ND & ND & $\mathrm{ND}$ & ND & Q10 \\
\hline $\mathrm{G}+\mathrm{C}$ content $(\mathrm{mol} \%)$ & $64 \cdot 5$ & $64 \cdot 4$ & $59 \cdot 7$ & $62 \cdot 3-62 \cdot 8$ & $54 \cdot 0$ & $63-63 \cdot 1$ & $60 \cdot 5$ & 57 & $56 \cdot 3-58 \cdot 1$ & $62 \cdot 2-63 \cdot 3$ & $64-65$ & 65 & $66 \cdot 2$ & 59 & $55-56 \cdot 3$ \\
\hline
\end{tabular}

${ }^{*} \mathrm{M}$, Multiple; S, single; SP, subpolar.

$\dagger \mathrm{AE}$, Aerobic; $\mathrm{CH}$, chemoheterotrophic; FA, facultatively anaerobic; M, methylotrophic; MA, microaerophilic.

$\ddagger$ Growth on minimum medium supplemented in some cases with growth factors.

§Only percentages higher than $1 \%$ are shown. 


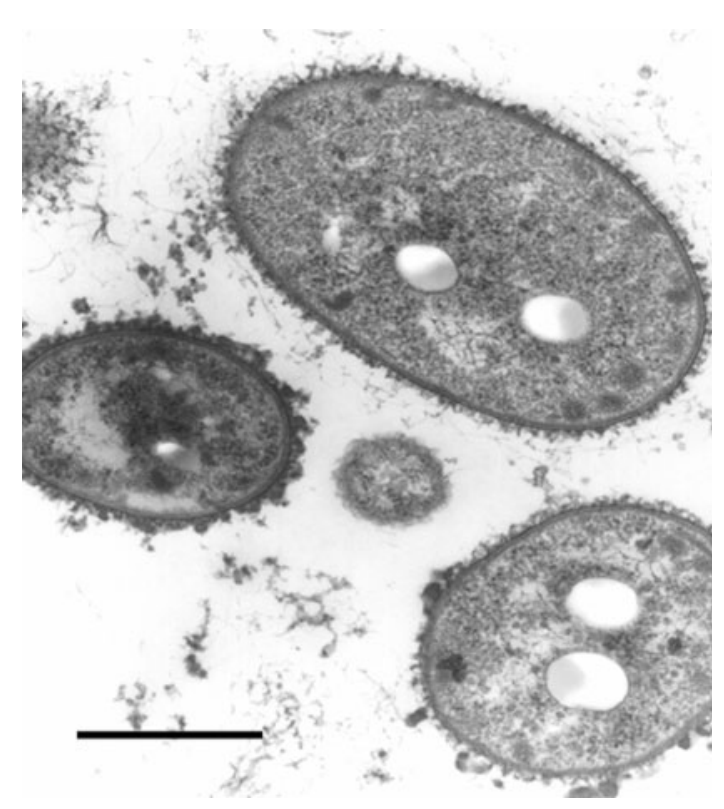

Fig. 1. Transmission electron micrograph of cells of strain $A 3^{\top}$ stained with ruthenium red. Bar, $1 \mu \mathrm{m}$. and Roseivivax halotolerans and shows $94 \%$ similarity to both species. This value indicates the possibility of a new taxon of at least genus status. The physiology of strain $A 3^{\mathrm{T}}$ is also clearly different from that of the Roseivivax species, which are pink-pigmented chemoheterotrophs that synthesize bacteriochlorophyll $a$ under aerobic conditions, produce acids from sugars and are able to use different compounds as sole sources of carbon and energy. Thus, on the basis of phylogenetic evidence, differences in phenotypic characteristics and its inability to synthesize bacteriochlorophyll $a$, we are of the opinion that strain $\mathrm{A} 3^{\mathrm{T}}$ should be recognized as a new genus with a single species, for which we propose the name Salipiger mucescens gen. nov., sp. nov. The genus is in the same clade as that of Roseivivax, belonging to the $\alpha-3$ group of the $\alpha$-subclass of the Proteobacteria, within the family 'Rhodobacteraceae' (Garrity \& Holt, 2001). Members of this taxon are in general non-sulfur, purple bacteria that carry out anoxygenic photosynthesis. This family includes a group of aerobic bacteriochlorophyll-containing bacteria (ABC), to which Roseivivax pertains (Imhoff \& Madigan, 2002). Roseivivax is taxonomically related to the Roseobacter clade, a group of 11 genera of the family 'Rhodobacteraceae' (Allgaier et al.,

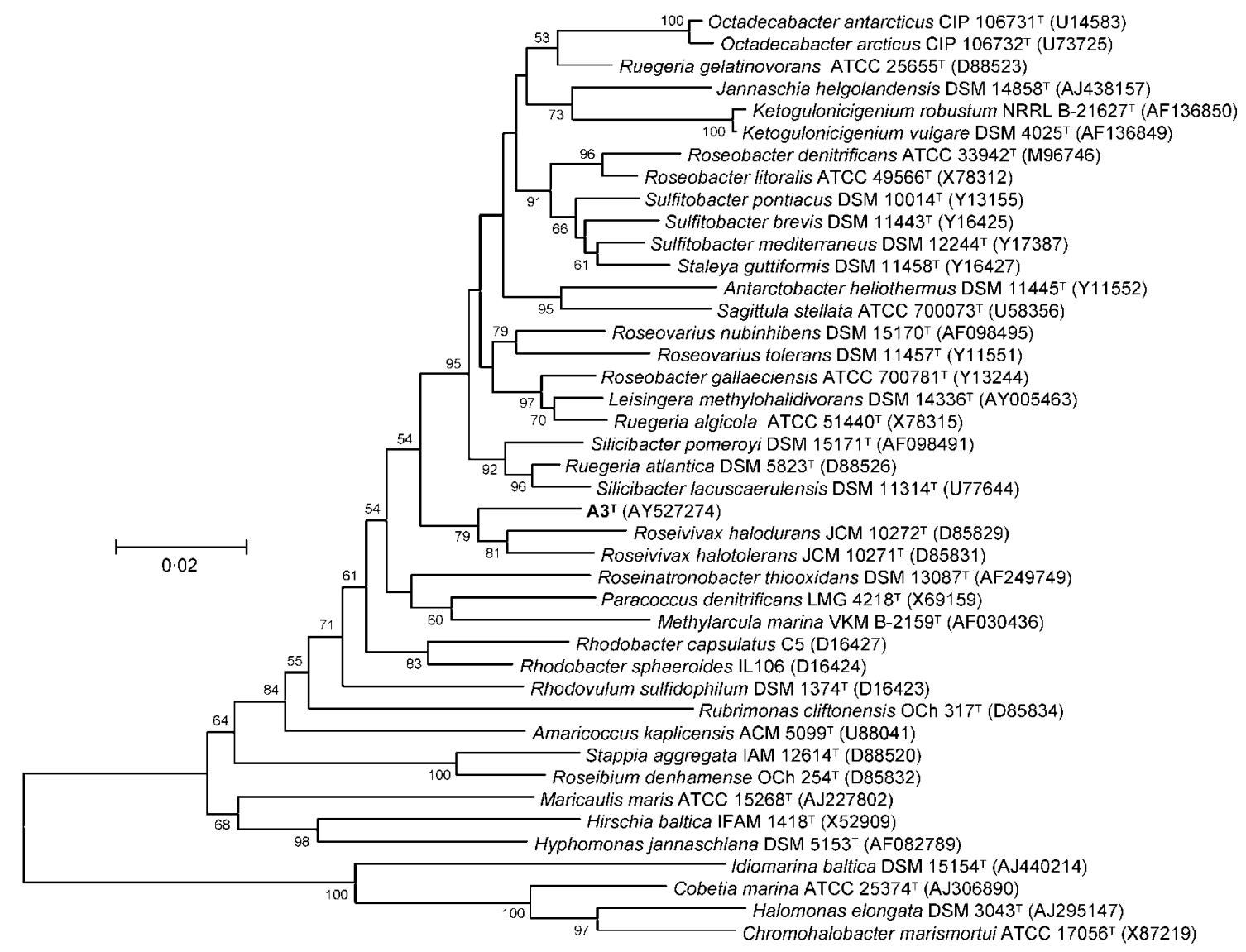

Fig. 2. Phylogenetic relationships amongst Salipiger mucescens $A 3^{\top}$ and members of other genera of the family 'Rhodobacteraceae' plus other taxa of Gram-negative halophilic bacteria. The tree was constructed using the neighbourjoining algorithm. Only bootstrap values above $50 \%$ are shown (1000 replications). Bar, $2 \%$ estimated sequence divergence. 
2003), which make up the most abundant populations in marine habitats (González \& Moran, 1997).

\section{Description of Salipiger gen. nov.}

Salipiger (Sa.li.pi'ger. L. masc. sb. sal salt; L. masc. adj. piger lazy; N.L. masc. sb. Salipiger lazy halophile).

Gram-negative, non-motile rods, $2-2 \cdot 5 \mu \mathrm{m}$ long by $0 \cdot 75-$ $1 \mu \mathrm{m}$ wide. Chemoheterotrophic, strictly aerobic, being unable to grow under anaerobic conditions either by fermentation, nitrate or fumarate reduction or photoheterotrophy. PHA, cytochrome oxidase and catalase are present. Low nutritional and biochemical versatility. Strictly halophilic, requiring $\mathrm{Na}^{+}$ions for growth. The principal cellular fatty acids are $18: 1 \omega 7 c$ and $16: 0$. It has ubiquinone with ten isoprene units. The type species is Salipiger mucescens.

\section{Description of Salipiger mucescens sp. nov.}

Salipiger mucescens (mu.ces'cens. L. masc. ppl. adj. mucescens slimy).

In addition to the traits reported for the genus, the species grows on MY solid medium in the form of circular, convex, cream-coloured, mucoid colonies. In liquid medium its growth pattern is uniform. The cells are encapsulated. It is moderately halophilic, capable of growing in salt concentrations (mixture of sea salts) from 0.5 to $20 \% \mathrm{w} / \mathrm{v}$, the optimum range being between 3 and $6 \% \mathrm{w} / \mathrm{v}$. Nevertheless, if $\mathrm{NaCl}$ is substituted for sea salts, the concentration required for optimum growth reaches values of 9 to $10 \%$ $\mathrm{w} / \mathrm{v}$. It grows within the temperature range of 20 to $40^{\circ} \mathrm{C}$ and at $\mathrm{pH}$ values of between 6 and 10 . It produces $\mathrm{H}_{2} \mathrm{~S}$ from L-cysteine. Selenite reduction, gluconate oxidation and phosphatase are positive. Urea and Tween 20 are hydrolysed. It does not produce acids from the following sugars: adonitol, D-cellobiose, D-fructose, D-galactose, D-glucose, myo-inositol, lactose, maltose, D-mannitol, D-mannose, D-melezitose, L-rhamnose, sucrose, D-salicin, D-sorbitol, sorbose and D-trehalose. O/F, ONPG, indole, methyl-red and Voges-Proskauer are negative. Phenylalanine deaminase is not produced. Tyrosine, Tween 80 , starch, aesculin, gelatin, DNA, lecithin and casein are not hydrolysed. Growth on either MacConkey or cetrimide agar is unviable. Blood is not haemolysed. Neither nitrate nor nitrite is reduced. The following compounds are not acceptable as sole carbon and energy sources: L-arabinose, D-cellobiose, aesculin, D-fructose, D-glucose, D-galactose, lactose, maltose, D-mannose, D-salicin, acetate, citrate, formate, fumarate, glycerol, lactate, malonate, propionate and succinate. The following compounds are not used as sole carbon, nitrogen and energy sources: L-alanine, L-cysteine, L-histidine, isoleucine, L-lysine, L-methionine, L-serine and $\mathrm{L}$-valine. It is susceptible to $(\mu \mathrm{g})$ amoxicillin (25), ampicillin (10), carbenicillin (100), cefotaxime (30), cefoxitin (30), chloramphenicol (30), erythromycin (15), kanamycin (30), nitrofurantoin (300), rifampicin (30), sulfonamide (250), tobramycin (10) and trimetoprim/sulphametoxazol
$(1 \cdot 25 / 23 \cdot 7)$, and is resistant to nalidixic acid (30) and polymixin $\mathrm{B}(300)$. The major fatty acids $(\%)$ are $18: 1 \omega 7 c$ $(78 \cdot 0), 16: 0(12 \cdot 4), 12: 13-\mathrm{OH}(2 \cdot 3), 19: 0$ cyclo $\omega 8 c(2 \cdot 3)$, $18: 0(2 \cdot 0)$ and $16: 1 \omega 7 c / 15: 0$ iso $2-\mathrm{OH}(1 \cdot 3)$. Its DNA $\mathrm{G}+\mathrm{C}$ content is $64 \cdot 5 \mathrm{~mol} \%$ ( $T_{\mathrm{m}}$ method).

The type strain is strain $\mathrm{A}^{\mathrm{T}}\left(=\mathrm{CECT} 5855^{\mathrm{T}}=\mathrm{LMG}\right.$ $22090^{\mathrm{T}}=\mathrm{DSM} 16094^{\mathrm{T}}$ ), isolated from a hypersaline soil taken from a solar saltern in Calblanche (Murcia, southeastern Spain).

\section{Acknowledgements}

This research was supported by grants from the Dirección General de Investigación Científica y Técnica (BOS2000-1519) and from the Plan Andaluz de Investigación, Spain. The authors are very grateful to C. Fernández and D. Porcel for their expertise in the electronmicroscope studies and to our colleague Dr J. Trout for revising the English text. Thanks also go to Professor H. G. Trüper of the University of Bonn for his help with the genus and species names.

\section{References}

Allgaier, M., Uphoff, H., Feelske, A. \& Wagner-Döbler, I. (2003). Aerobic anoxygenic photosynthesis in Roseobacter clade bacteria from diverse marine habitats. Appl Environ Microbiol 69, 5051-5059.

Argandoña, M., Martínez-Checa, F., Llamas, I., Quesada, E. \& Del Moral, A. (2003). Megaplasmids in Gram-negative, moderately halophilic bacteria. FEMS Microbiol Lett 227, 81-86.

Bouchotroch, S., Quesada, E., del Moral, A., Llamas, I. \& Béjar, V. (2001). Halomonas maura sp. nov., a novel moderately halophilic, exopolysaccharide-producing bacterium. Int J Syst Evol Microbiol 51, 1625-1632.

Brosius, J., Palmer, M. L., Kennedy, P. J. \& Noller, H. F. (1978). Complete nucleotide sequence of a $16 \mathrm{~S}$ ribosomal RNA gene from Escherichia coli. Proc Natl Acad Sci U S A 75, 4801-4805.

Cohen-Bazire, G., Sistrom, W. R. \& Stanier, R. Y. (1957). Kinetic studies of pigment synthesis by non-sulfur purple bacteria. J Cell Comp Physiol 49, 25-68.

Garrity, G. M. \& Holt, J. G. (2001). The road map to the Manual. In Bergey's Manual of Systematic Bacteriology, 2nd edn, vol. 1, pp. 119-166. Edited by D. R. Boone, R. W. Castenholz \& G. M. Garrity. New York: Springer.

González, J. M. \& Moran, M. A. (1997). Numerical dominance of a group of marine bacteria in the $\alpha$-subclass of the class Proteobacteria in coastal seawater. Appl Environ Microbiol 63, 4237-4242.

González, J. M., Mayer, F., Moran, M. A., Hodson, R. E. \& Whitman, W. B. (1997). Sagittula stellata gen. nov., sp. nov., a lignintransforming bacterium from a coastal environment. Int $J$ Syst Bacteriol 47, 773-780.

Gosink, J. J., Herwig, R. P. \& Staley, J. T. (1997). Octadecabacter arcticus gen. nov., sp. nov., and $O$. antarcticus, sp. nov., nonpigmented, psychrophilic gas vacuolate bacteria from polar sea ice and water. Syst Appl Microbiol 20, 356-365.

Imhoff, J. F. \& Madigan, M. T. (2002). International Committee on Systematics of Prokaryotes Subcommittee on the taxonomy of phototrophic bacteria. Minutes of the meetings, 28 August 2000, Barcelona, Spain. Int J Syst Evol Microbiol 52, 2335-2336.

Kumar, S., Tamura, K., Jakobsen, I. B. \& Nei, M. (2001). MEGA2: Molecular Evolutionary Genetics Analysis software. Bioinformatics 17, 1244-1245. 
Kushner, D. J. \& Kamekura, M. (1988). Physiology of halophilic bacteria. In Halophilic Bacteria, pp. 109-138. Edited by F. RodríguezValera. Boca Raton, FL: CRC Press.

Labrenz, M., Collins, M. D., Lawson, P. A., Tindall, B. J., Braker, G. \& Hirsch, P. (1998). Antarctobacter heliothermus gen. nov., sp. nov., a budding bacterium from hypersaline and heliothermal Ekho Lake. Int J Syst Bacteriol 48, 1363-1372.

Labrenz, M., Collins, M. D., Lawson, P. A., Tindall, B. J., Schumann, P. \& Hirsch, P. (1999). Roseovarius tolerans gen. nov., sp. nov., a budding bacterium with variable bacteriochlorophyll a production from hypersaline Ekho lake. Int J Syst Bacteriol 49, 137-147.

Labrenz, M., Tindall, B. J., Lawson, P. A., Collins, M. D., Schumann, P. \& Hirsch, P. (2000). Staleya guttiformis gen. nov., sp. nov. and Sulfitobacter brevis sp. nov., $\alpha$-3-Proteobacteria from hypersaline, heliothermal and meromictic antarctic Ekho Lake. Int J Syst Evol Microbiol 50, 303-313.

Lafay, B., Ruimy, R., Rausch de Traubenberg, C., Breittmayer, V., Gauthier, M. J. \& Christen, R. (1995). Roseobacter algicola sp. nov., a new marine bacterium isolated from the phycosphere of the toxinproducing dinoflagellate Prorocentrum lima. Int J Syst Bacteriol 45, 290-296.

Martínez-Cánovas, M. J., Quesada, E., Llamas, I. \& Béjar, V. (2004a). Halomonas ventosae sp. nov., a moderately halophilic, denitrifying, exopolysaccharide-producing bacterium. Int J Syst Evol Microbiol 54, 733-737.

Martínez-Cánovas, M. J., Béjar, V., Martínez-Checa, F. \& Quesada, E. (2004b). Halomonas anticariensis sp. nov., from Fuente de Piedra, a saline-wetland wildfowl reserve in Málaga, southern Spain. Int J Syst Evol Microbiol 54, 1329-1332.

Martínez-Cánovas, M. J., Quesada, E., Martínez-Checa, F. \& Béjar, V. (2004c). A taxonomic study to establish the relationship between exopolysaccharide-producing bacterial strains living in diverse hypersaline habitats. Curr Microbiol 48, 348-353.

Nishimura, Y., Muroga, Y., Saito, S., Shiba, T., Takamiya, K. \& Shioi, Y. (1994). DNA relatedness and chemotaxonomic feature of aerobic bacteriochlorophyll-containing bacteria isolated from coasts of Australia. J Gen Appl Microbiol 40, 287-296.

Petursdottir, S. K. \& Kristjansson, J. K. (1997). Silicibacter lacuscaerulensis gen. nov., sp. nov., a mesophilic moderately halophilic bacterium characteristic of the Blue lagoon geothermal lake in Iceland. Extremophiles 1, 94-99.

Pukall, R., Buntefuß, D., Frühling, A., Rohde, M., Kroppenstedt, R. M., Burghardt, J., Lebaron, P., Bernard, L. \& Stackebrandt, E. (1999). Sulfitobacter mediterraneus sp. nov., a new sulfite-oxidizing member of the $\alpha$-Proteobacteria. Int J Syst Bacteriol 49, 513-519.

Quesada, E., Valderrama, M. J., Béjar, V., Ventosa, A., Gutierrez, M. C., Ruiz-Berraquero, F. \& Ramos-Cormenzana, A. (1990).
Volcaniella eurihalina gen. nov., sp. nov., a moderately halophilic nonmotile gram-negative rod. Int J Syst Bacteriol 40, 261-267.

Quesada, E., Béjar, V. \& Calvo, C. (1993). Exopolysaccharide production by Volcaniella eurihalina. Experientia 49, 1037-1041.

Quesada, E., Béjar, V., Ferrer, M. R. \& 8 other authors (2004). Moderately halophilic, exopolysaccharide-producing bacteria. In Halophilic Microorganisms, pp. 297-314. Edited by A. Ventosa. Heidelberg: Springer.

Rodríguez-Valera, F., Ruiz-Berraquero, F. \& Ramos-Cormenzana, A. (1981). Characteristics of the heterotrophic bacterial populations in hypersaline environments of different salt concentrations. Microb Ecol 7, 235-243.

Saiki, R. K., Gelfand, D. H., Stoffel, S., Scharf, S. J., Higuchi, R., Horn, G. T., Mullis, K. B. \& Erlich, H. A. (1988). Primer-directed enzymatic amplification of DNA with thermostable DNA polymerase. Science 239, 487-491.

Schaefer, J. K., Goodwin, K. D., McDonald, I. R., Murrell, J. C. \& Oremland, R. S. (2002). Leisingera methylohalidivorans gen. nov., sp. nov., a marine methylotroph that grows on methyl bromide. Int J Syst Evol Microbiol 52, 851-859.

Shiba, T. (1991). Roseobacter litoralis gen. nov., and Roseobacter denitrificans sp. nov., aerobic pink-pigmented bacteria which contain bacteriochlorophyll a. Syst Appl Microbiol 14, 140-145.

Stackebrandt, E., Fredricksen, W., Garrity, G. M. \& 10 other authors (2002). Report of the ad hoc committee for the re-evaluation of the species definition in bacteriology. Int J Syst Evol Microbiol 52, 1043-1047.

Suzuki, T., Muroga, Y., Takahama, M. \& Nishimura, Y. (1999). Roseivivax halodurans gen. nov., sp. nov. and Roseivivax halotolerans sp. nov., aerobic bacteriochlorophyll-containing bacteria isolated from a saline lake. Int J Syst Bacteriol 49, 629-634.

Thompson, J. D., Gibson, T. J., Plewniak, K., Jeanmougin, F. \& Higgins, D. G. (1997). The CLUSTAL_X windows interface: flexible strategies for multiple sequence alignments aided by quality analysis tools. Nucleic Acids Res 25, 4876-4882.

Urbance, J. W., Bratina, B. J., Stoddard, S. F. \& Schmidt, T. M. (2001). Taxonomic characterization of Ketogulonigenium vulgare gen. nov., sp. nov. and Ketogulonigenium robustum sp. nov., which oxidize L-sorbose to 2-keto-L-gulonic acid. Int J Syst Evol Microbiol 51, 1059-1070.

Ventosa, A. (editor) (2004). Halophilic Microorganisms. Heidelberg: Springer.

Ventosa, A., Nieto, J. J. \& Oren, A. (1998). Biology of moderately halophilic aerobic bacteria. Microbiol Mol Biol Rev 62, 504-544.

Wagner-Döbler, I., Rheims, H., Felske, A., Pukall, R. \& Tindall, B. J. (2003). Jannaschia helgolandensis gen. nov., sp. nov., a novel abundant member of the marine Roseobacter clade from the North Sea. Int J Syst Evol Microbiol 53, 731-738. 